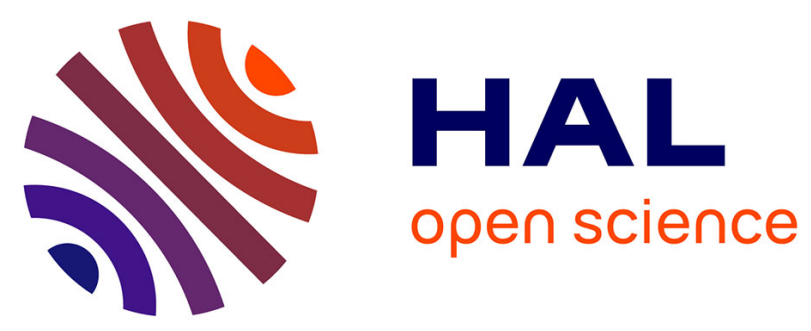

\title{
Promoting Ag/Al2O3 Performance in Low-Temperature H2-C3H6-SCR by Thermal Pretreatment of $\gamma$-Alumina in Water
}

Tesnim Chaieb, Laurent Delannoy, Catherine Louis, Cyril Thomas

\section{- To cite this version:}

Tesnim Chaieb, Laurent Delannoy, Catherine Louis, Cyril Thomas. Promoting Ag/Al2O3 Performance in Low-Temperature H2-C3H6-SCR by Thermal Pretreatment of $\gamma$-Alumina in Water. Catalysis Letters, 2016, pp.1-8. 10.1007/s10562-016-1864-9 . hal-01390045

\section{HAL Id: hal-01390045 \\ https: / hal.sorbonne-universite.fr/hal-01390045}

Submitted on 31 Oct 2016

HAL is a multi-disciplinary open access archive for the deposit and dissemination of scientific research documents, whether they are published or not. The documents may come from teaching and research institutions in France or abroad, or from public or private research centers.
L'archive ouverte pluridisciplinaire HAL, est destinée au dépôt et à la diffusion de documents scientifiques de niveau recherche, publiés ou non, émanant des établissements d'enseignement et de recherche français ou étrangers, des laboratoires publics ou privés. 


\section{Promoting $\mathrm{Ag} / \mathrm{Al}_{2} \mathrm{O}_{3}$ performance in low-temperature}

\section{$\mathrm{H}_{2}-\mathrm{C}_{3} \mathrm{H}_{6}-\mathrm{SCR}$ by thermal pretreatment of $\gamma$-alumina in water}

Tesnim Chaieb, Laurent Delannoy, Catherine Louis and Cyril Thomas*

1- Sorbonne Universités, UPMC Univ Paris 06, UMR CNRS 7197, Laboratoire de Réactivité

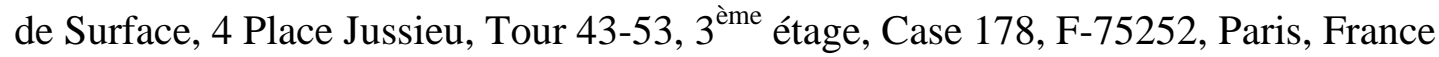

Running title: Promoting $\mathrm{Ag} / \mathrm{Al}_{2} \mathrm{O}_{3}$ performance in $\mathrm{H}_{2}-\mathrm{C}_{3} \mathrm{H}_{6}-\mathrm{SCR}$

* To whom correspondence should be addressed:

Dr. Cyril Thomas

Sorbonne Universités, UPMC Univ Paris 06, UMR CNRS 7197, Laboratoire de Réactivité de Surface, 4 Place Jussieu, Tour 43-53, $3^{\text {ème }}$ étage, Case 178, F-75252, Paris, France e-mail: cyril.thomas@upmc.fr

Tel: + 33144273630

Fax: + 33144276033 


\begin{abstract}
:
The present work highlights for the first time that a thermal treatment of $\gamma-\mathrm{Al}_{2} \mathrm{O}_{3}$ in water at $80{ }^{\circ} \mathrm{C}$ for $24 \mathrm{~h}$ prior to $\mathrm{Ag}$ deposition $\left(\mathrm{Ag} / \mathrm{Al}_{2} \mathrm{O}_{3}-\mathrm{OH}\right)$ leads to a drastic enhancement of $\mathrm{H}_{2}-\mathrm{C}_{3} \mathrm{H}_{6}-\mathrm{SCR}$ performance at low temperature. This enhancement is attributed to the higher $\mathrm{NO}_{x}$ coverage on $\mathrm{Ag} / \mathrm{Al}_{2} \mathrm{O}_{3}-\mathrm{OH}$ compared with that of $\mathrm{Ag} / \mathrm{Al}_{2} \mathrm{O}_{3}$. The higher $\mathrm{NO}_{x}$ adsorption capacity of the sample prepared from the $\gamma-\mathrm{Al}_{2} \mathrm{O}_{3}$ thermally-treated in water is proposed to result from the preferential interaction of $\mathrm{Ag}$ with newly-created $\mathrm{Al}_{2} \mathrm{O}_{3}$ anchoring sites $\left(\mathrm{Al}(\mathrm{OH})_{3}\right.$ bayerite domains $)$, which were not available on the untreated pristine support.
\end{abstract}

Key Words: Selective Catalytic Reduction; $\mathrm{NO}_{x}$-TPD; UV-vis 


\section{Introduction}

Since the implementation of catalytic converters dedicated to the concomitant reduction of nitrogen oxides $\left(\mathrm{NO}_{x}=\mathrm{NO}+\mathrm{NO}_{2}\right)$ and oxidations of carbon monoxide $(\mathrm{CO})$ and unburned hydrocarbons (HCs) in the early 1970s, the environmental challenge has moved to the reduction of $\mathrm{NO}_{x}$ from lean exhausts at low temperatures [1]. Even though the Selective Catalytic Reduction of $\mathrm{NO}_{x}$ by ammonia $\left(\mathrm{NH}_{3}-\mathrm{SCR}\right)$ and Lean- $\mathrm{NO}_{x}$ Traps (LNT) remain as the only technologies to comply with the current emission standards, these two technologies exhibit drawbacks [1,2] and many studies have been devoted to seek out for alternative processes such as the reduction of $\mathrm{NO}_{x}$ by hydrocarbons (Hydrocarbon Selective Catalytic Reduction: HC-SCR).

In 1993, Miyadera firstly brought to the attention of the community that $\mathrm{Ag} / \mathrm{Al}_{2} \mathrm{O}_{3}$ could be a promising catalyst in HC-SCR with various light hydrocarbons [3]. Few years later, Satokawa and co-workers discovered that the performance of the $\mathrm{Ag} / \mathrm{Al}_{2} \mathrm{O}_{3}$ catalyst could be improved drastically at low temperatures (below $300{ }^{\circ} \mathrm{C}$ ) on the addition of small quantities of $\mathrm{H}_{2}$ in the reacting feed $\left(\mathrm{H}_{2}-\mathrm{HC}-\mathrm{SCR}\right)$ [4,5]. The $\mathrm{Ag} / \mathrm{Al}_{2} \mathrm{O}_{3}$ system has been investigated thoroughly until recently [6-8].

Since these pioneering works, no major improvement of the $\mathrm{Ag} / \mathrm{Al}_{2} \mathrm{O}_{3}$ system has been achieved up to the works of Kamolphop et al. [9] and Petitto and Delahay [10] in which superior HC-SCR performance was obtained using long-chain alkanes as reductants and catalysts prepared by ball-milling compared with those synthesized by the conventional impregnation techniques reported to date. Ball-milled prepared $\mathrm{Ag} / \mathrm{Al}_{2} \mathrm{O}_{3}$ catalysts were also found to exhibit higher $\mathrm{H}_{2}$-HC-SCR activities in comparison with the conventionally prepared samples [11,12]. This was inferred to modifications of the catalyst surface and more specifically to changes in the affinity of the $\mathrm{Al}_{2} \mathrm{O}_{3}$ surface towards water and decane [11]. In addition, it was found that isocyanates $(-\mathrm{NCO})$, which are supposed to be key intermediates 
of HC-SCR reactions [1], were formed quicker and had a higher surface concentration on the ball-milled catalyst compared with the conventionally prepared sample [11,12].

Since it has been proposed that $\mathrm{Ag}$ anchored onto the $\mathrm{Al}_{2} \mathrm{O}_{3}$ support via the interaction with its hydroxyl groups $\left(\mathrm{Al}-\mathrm{OH}+\mathrm{Ag}^{+}=\mathrm{Al}-\mathrm{O}-\mathrm{Ag}+\mathrm{H}^{+}\right)$during the impregnation step [13] and that hydroxylation of $\mathrm{Al}_{2} \mathrm{O}_{3}$ occurs when immersed into water under various experimental conditions (temperature, pressure, $\mathrm{pH}$, time of exposure) [14-16], we found of particular interest to investigate the influence of the hydroxylation of $\gamma-\mathrm{Al}_{2} \mathrm{O}_{3}$ prior to $\mathrm{Ag}$ deposition on $\mathrm{C}_{3} \mathrm{H}_{6^{-}}$and $\mathrm{H}_{2}-\mathrm{C}_{3} \mathrm{H}_{6}-\mathrm{SCR}$ catalytic performance. To our knowledge, such an approach has never been reported previously for the $\mathrm{Ag} / \mathrm{Al}_{2} \mathrm{O}_{3}$ system, but recently in the case of the $\mathrm{Pt} / \mathrm{Al}_{2} \mathrm{O}_{3}$ system for other catalytic reactions [17].

\section{Experimental}

\subsection{Catalyst synthesis}

Hydroxylation of the $\gamma-\mathrm{Al}_{2} \mathrm{O}_{3}$ support (Procatalyse, $180 \mathrm{~m}^{2} / \mathrm{g}$ ) was carried out by heating this oxide in distilled water at $80{ }^{\circ} \mathrm{C}$ for $24 \mathrm{~h}$ under vigorous stirring. After filtering, the solid was dried and kept under vacuum at RT. Ag was deposited following the incipient wetness procedure described in our earlier works [6,8]. Briefly, Ag was deposited via incipient wetness impregnation of an aqueous solution $\mathrm{AgNO}_{3}$ (Aldrich, >99\%) on the hydroxylated $\mathrm{Al}_{2} \mathrm{O}_{3}$ sample $\left(0.7 \mathrm{~cm}^{3} / g\right.$ porous volume $)$ to achieve a silver loading of $1.9 \mathrm{wt} \%$, which was ascertained by inductively coupled plasma atomic emission spectroscopy (ICPAES, Centre d'Analyse du CNRS, Solaize, France). In parallel, a new batch of $\mathrm{Ag} / \mathrm{Al}_{2} \mathrm{O}_{3}$ sample was prepared from the as-received $\mathrm{Al}_{2} \mathrm{O}_{3}$ support following the abovementioned $\mathrm{Ag}$ deposition procedure. From here on, the samples prepared from hydroxylated $\mathrm{Al}_{2} \mathrm{O}_{3}$ will be denoted as $\mathrm{Al}_{2} \mathrm{O}_{3}-\mathrm{OH}$ and $\mathrm{Ag} / \mathrm{Al}_{2} \mathrm{O}_{3}-\mathrm{OH}$ and compared with the samples synthesized from the 
untreated support denoted as $\mathrm{Al}_{2} \mathrm{O}_{3}$ and $\mathrm{Ag} / \mathrm{Al}_{2} \mathrm{O}_{3}$ (1.8 wt $\%$ Ag) either newly-prepared or studied earlier $[6,8]$.

\section{2. $\mathrm{C}_{3} \mathrm{H}_{6}-\mathrm{SCR}$ and $\mathrm{H}_{2}-\mathrm{C}_{3} \mathrm{H}_{6}-\mathrm{SCR}$ runs}

The steady state catalytic $\mathrm{C}_{3} \mathrm{H}_{6}-\mathrm{SCR}$ and $\mathrm{H}_{2}-\mathrm{C}_{3} \mathrm{H}_{6}$-SCR experiments were carried out in a U-type quartz reactor (12 $\mathrm{mm}$ i.d.). The temperature of the tubular furnace was set by a Eurotherm 2408 temperature controller using a K type thermocouple. Prior to the SCR experiments, the samples $\left(0.18 \mathrm{~g}\right.$ of $\mathrm{Ag} / \mathrm{Al}_{2} \mathrm{O}_{3}$ or $\mathrm{Ag} / \mathrm{Al}_{2} \mathrm{O}_{3}-\mathrm{OH}$ diluted in $0.18 \mathrm{~g}$ of $\mathrm{Al}_{2} \mathrm{O}_{3}$, $125-200 \mu \mathrm{m})$ were calcined in situ in $\mathrm{O}_{2}(20 \%)-\mathrm{He}$ at $550{ }^{\circ} \mathrm{C}\left(3{ }^{\circ} \mathrm{C} / \mathrm{min}\right)$ for $2 \mathrm{~h}$ with a flow rate of $100 \mathrm{~mL} \mathrm{NTP}_{\mathrm{min}}$. After cooling to $150{ }^{\circ} \mathrm{C}$, the samples were submitted to a $\mathrm{C}_{3} \mathrm{H}_{6}-\mathrm{SCR}$ experiment from 150 to $550{ }^{\circ} \mathrm{C}$ [6]. The samples were subsequently exposed to the $\mathrm{H}_{2}-\mathrm{C}_{3} \mathrm{H}_{6}$ SCR feed at $150{ }^{\circ} \mathrm{C} . \mathrm{H}_{2}(2 \% / \mathrm{He}), \mathrm{NO}(4000 \mathrm{ppm} / \mathrm{He}), \mathrm{C}_{3} \mathrm{H}_{6}(2000 \mathrm{ppm} / \mathrm{He}), \mathrm{O}_{2}(100 \%)$ and He (100\%) were fed from independent cylinders (Air Liquide) without any further purification via mass flow controllers (Brooks 5850TR). Typically, the composition of the SCR feeds was: 0 or $0.21 \% \mathrm{H}_{2}, 385$ ppm $\mathrm{NO}_{x}(\sim 96 \% \mathrm{NO}), 400 \mathrm{ppm} \mathrm{C}_{3} \mathrm{H}_{6}$ and $8 \% \mathrm{O}_{2}$ in $\mathrm{He}$, and the total flow rate was $230 \mathrm{~mL} \mathrm{NTP}_{\mathrm{min}}$. In both SCR experiments, the temperature was increased stepwise from 150 to $550{ }^{\circ} \mathrm{C}$ with $25{ }^{\circ} \mathrm{C}$ increments and left for about $1 \mathrm{~h}$ at each temperature step. Steady state activity was found to be achieved shortly for all reaction temperatures. The reactor outflow was analyzed using a $\mu$-GC (Agilent Technologies, CP4900) equipped with two channels. The first channel, a 5A molecular sieve column $\left(80{ }^{\circ} \mathrm{C}\right.$, $150 \mathrm{kPa} \mathrm{He}, 200 \mathrm{~ms}$ injection time, $30 \mathrm{~s}$ backflush time), was used to separate $\mathrm{N}_{2}, \mathrm{O}_{2}$ and $\mathrm{CO}$. The second channel, equipped with a poraplot Q column $\left(60{ }^{\circ} \mathrm{C}, 150 \mathrm{kPa} \mathrm{He}, 200 \mathrm{~ms}\right.$ injection time), was used to separate $\mathrm{CO}_{2}, \mathrm{~N}_{2} \mathrm{O}, \mathrm{C}_{3} \mathrm{H}_{6}$ and $\mathrm{H}_{2} \mathrm{O}$. A chemiluminescence $\mathrm{NO}_{x}$ analyzer (Thermo Environmental Instruments 42C-HT) allowed the simultaneous detection of both $\mathrm{NO}$ and $\mathrm{NO}_{2}$. $\mathrm{NO}_{x}$ conversion to $\mathrm{N}_{2}$ and $\mathrm{N}_{2}$ selectivity were calculated as follows: 


$$
\begin{aligned}
& \left.X_{\mathrm{NO} x \text { to } 2}(\%)=\left(2 \times\left[\mathrm{N}_{2}\right]\right) /\left[\mathrm{NO}_{x}\right]_{\text {inlet }}\right) \times 100 \\
& S_{N 2}(\%)=\left(\left[\mathrm{N}_{2}\right] /\left[\mathrm{N}_{2}+\mathrm{N}_{2} \mathrm{O}\right]\right) \times 100
\end{aligned}
$$

where $\left[\mathrm{NO}_{x}\right]_{\text {inlet }}$, $\left[\mathrm{N}_{2}\right]$ and $\left[\mathrm{N}_{2} \mathrm{O}\right]$ were the concentrations in $\mathrm{NO}_{x}$ measured at the inlet of the reactor and in $\mathrm{N}_{2}$ and $\mathrm{N}_{2} \mathrm{O}$ at the outlet of the reactor. $\mathrm{C}_{3} \mathrm{H}_{6}$ conversions were calculated on the basis of the $\mathrm{CO}_{x}\left(\mathrm{CO}+\mathrm{CO}_{2}\right)$ products formed:

$$
X_{\mathrm{C} 3 \mathrm{H} 6}(\%)=\left(\left([\mathrm{CO}]+\left[\mathrm{CO}_{2}\right]\right) /\left(\left[\mathrm{C}_{3} \mathrm{H}_{6}\right]_{\text {inlet }} \times 3\right)\right) \times 100
$$

where $[\mathrm{CO}],\left[\mathrm{CO}_{2}\right]$ and $\left[\mathrm{C}_{3} \mathrm{H}_{6}\right]_{\text {inlet }}$ were the concentrations of $\mathrm{CO}$ and $\mathrm{CO}_{2}$ measured at the outlet of the reactor and that of $\mathrm{C}_{3} \mathrm{H}_{6}$ measured at the inlet of the reactor, respectively.

\subsection{Catalyst characterization}

$\mathrm{N}_{2}$-sorption measurements were carried out on a Belsorp max instrument (Bel Japan) at $77 \mathrm{~K}$. It was found that the BET surface of the hydroxylated samples both after drying at $120{ }^{\circ} \mathrm{C}$ for $12 \mathrm{~h}$ in an oven and calcination at $550{ }^{\circ} \mathrm{C}$ for $2 \mathrm{~h}$ in a muffle furnace $\left(185 \mathrm{~m}^{2} / \mathrm{g}\right)$ did not vary to a significant extent from that of the starting $\mathrm{Al}_{2} \mathrm{O}_{3}$ support $\left(180 \mathrm{~m}^{2} / \mathrm{g}\right)$.

XRD measurements were carried out from 10 to $80^{\circ}$ by step of $0.01^{\circ}$ using a thetatheta D8 Advance (Bruker) powder diffractometer with $\mathrm{Cu}-\mathrm{K} \alpha$ radiation $(0.154 \mathrm{~nm})$ operated at $30 \mathrm{kV}$ and $30 \mathrm{~mA}$, and equipped with a $1 \mathrm{D}$ LynxEye detector set to a $3^{\circ}$ opening.

The ultraviolet-visible diffuse reflectance spectra (UV-vis DRS) of $\mathrm{Ag} / \mathrm{Al}_{2} \mathrm{O}_{3}$ and $\mathrm{Ag} / \mathrm{Al}_{2} \mathrm{O}_{3}-\mathrm{OH}$ were collected on a spectrophotometer (Cary 5000, Varian) equipped with a diffuse reflectance cell at RT in ambient air from 200 to $600 \mathrm{~nm}$ after calcination at $550{ }^{\circ} \mathrm{C}$ for $2 \mathrm{~h}$ and using the corresponding calcined $\mathrm{Al}_{2} \mathrm{O}_{3}$ supports for the background spectra.

The hydroxylated materials were also characterized by the $\mathrm{NO}_{x}$-TemperatureProgrammed Desorption ( $\mathrm{NO}_{x}$-TPD) method $[6,18,19]$. Prior to the $\mathrm{NO}_{x}$-TPD experiments, the samples were calcined in situ under a flow rate of $100 \mathrm{~mL}_{\mathrm{NTP}} / \mathrm{min}$ of $20 \% \mathrm{O}_{2}$ in $\mathrm{He}$ at 500 ${ }^{\circ} \mathrm{C}\left(3{ }^{\circ} \mathrm{C} / \mathrm{min}\right)$ for $2 \mathrm{~h}$. The samples (about $0.2 \mathrm{~g}$ ) were firstly contacted with a $\mathrm{NO}-\mathrm{O}_{2}-\mathrm{He}$ 
(385 ppm-8\%-balance, $230 \mathrm{~mL}_{\mathrm{NTP}} / \mathrm{min}$ ) mixture at room temperature (RT) until recovery of the inlet $\mathrm{NO}_{x}$ concentration. The samples were then flushed with $\mathrm{O}_{2}(8 \%)-\mathrm{He}$ at $\mathrm{RT}$ to remove weakly adsorbed $\mathrm{NO}_{x}$ species until the disappearance of the $\mathrm{NO}_{x}$ species in the stream. The $\mathrm{NO}_{x}$-TPD experiments were carried out from $\mathrm{RT}$ to $550{ }^{\circ} \mathrm{C}$ at a heating rate of $3{ }^{\circ} \mathrm{C} / \mathrm{min}$ under a flow of $230 \mathrm{~mL} \mathrm{NTP}_{\mathrm{N}} / \mathrm{min}$ of $8 \% \mathrm{O}_{2}$ in He. The reactor outflow was continuously monitored using a chemiluminescence $\mathrm{NO}_{x}$ analyzer (Thermo Environmental Instruments 42C-HT) which allowed for the simultaneous detection of both $\mathrm{NO}$ and $\mathrm{NO}_{2}$.

\section{Results}

\subsection{SCR performance}

In the absence of $\mathrm{H}_{2}$ in the reacting feed $\left(\mathrm{C}_{3} \mathrm{H}_{6}-\mathrm{SCR}\right.$, Fig. 1), hydroxylation of $\mathrm{Al}_{2} \mathrm{O}_{3}$ prior to the addition of $\mathrm{Ag}$ was found to have little influence on the conversion of $\mathrm{NO}_{x}$ to $\mathrm{N}_{2}$ (Fig. 1a, black line) although the $\mathrm{N}_{2}$ selectivity was found to be lowered to a significant extent below $450{ }^{\circ} \mathrm{C}$ on the hydroxylated catalyst. Regarding $\mathrm{C}_{3} \mathrm{H}_{6}$ oxidation (Fig. 1b), it can be seen that the conversion profile of $\mathrm{Ag} / \mathrm{Al}_{2} \mathrm{O}_{3}$ was steeper than that observed on $\mathrm{Ag} / \mathrm{Al}_{2} \mathrm{O}_{3}-\mathrm{OH}$.

As expected from the pioneering work of Satokawa [4], the conversions of $\mathrm{NO}_{x}$ to $\mathrm{N}_{2}$ and $\mathrm{C}_{3} \mathrm{H}_{6}$ to $\mathrm{CO}_{x}$ occurred at much lower temperatures in the presence of $\mathrm{H}_{2}$ on both samples (Fig. 2) in comparison with the reaction ran in the absence of $\mathrm{H}_{2}$ (Fig. 1). The $\mathrm{C}_{3} \mathrm{H}_{6}$ and $\mathrm{H}_{2}$ oxidation profiles were found to be shifted to slightly higher temperature on $\mathrm{Ag} / \mathrm{Al}_{2} \mathrm{O}_{3}-\mathrm{OH}$ compared to $\mathrm{Ag} / \mathrm{Al}_{2} \mathrm{O}_{3}$ (Fig. 2b). Much more interesting are the results obtained regarding the reduction of $\mathrm{NO}_{x}$ to $\mathrm{N}_{2}$ (Fig. 2a). From 250 to $450{ }^{\circ} \mathrm{C}$, the catalyst prepared from the support thermally-treated in water $\left(\mathrm{Ag} / \mathrm{Al}_{2} \mathrm{O}_{3}-\mathrm{OH}\right)$ remarkably outperformed $\mathrm{Ag} / \mathrm{Al}_{2} \mathrm{O}_{3}$ that had been prepared conventionally, whereas $\mathrm{N}_{2}$ selectivity remained comparable on both samples (Fig. 2a). The conversion of $\mathrm{NO}_{x}$ to $\mathrm{N}_{2}$ reached $82 \%$ 
at $275{ }^{\circ} \mathrm{C}$ on $\mathrm{Ag} / \mathrm{Al}_{2} \mathrm{O}_{3}-\mathrm{OH}$, whereas $\mathrm{Ag} / \mathrm{Al}_{2} \mathrm{O}_{3}$ exhibited only $50 \%$ conversion at the same temperature.

One can note that the newly-prepared $\mathrm{Ag} / \mathrm{Al}_{2} \mathrm{O}_{3}$ sample showed reproducible $\mathrm{C}_{3} \mathrm{H}_{6^{-}}$ SCR and $\mathrm{H}_{2}-\mathrm{C}_{3} \mathrm{H}_{6}$-SCR performance compared to the sample studied earlier (Figs. 1 and 2). Another $\mathrm{Ag} / \mathrm{Al}_{2} \mathrm{O}_{3}-\mathrm{OH}$ sample was prepared under different $\mathrm{pH}$ conditions and its $\mathrm{SCR}$ and $\mathrm{H}_{2}$-SCR catalytic performance (not shown) was found to be close to that reported in Figs. 1 and 2. Considering all the above, the present results highlights for the first time on the beneficial effect of a thermal pretreatment of the pristine $\gamma-\mathrm{Al}_{2} \mathrm{O}_{3}$ support in water prior to $\mathrm{Ag}$ deposition on $\mathrm{H}_{2}-\mathrm{C}_{3} \mathrm{H}_{6}$-SCR performance. To gain further insights into the enhanced $\mathrm{H}_{2}$ $\mathrm{C}_{3} \mathrm{H}_{6}$-SCR performance of the $\mathrm{Ag}$ catalyst prepared from the $\gamma-\mathrm{Al}_{2} \mathrm{O}_{3}$ support thermallypretreated in water compared with that prepared from the as-received $\mathrm{Al}_{2} \mathrm{O}_{3}$, the samples were characterized by XRD, UV-visible spectroscopy and $\mathrm{NO}_{x}$-TPD.

\subsection{Catalyst characterization}

XRD characterization of $\mathrm{Al}_{2} \mathrm{O}_{3}, \mathrm{Al}_{2} \mathrm{O}_{3}-\mathrm{OH}$ and calcined $\mathrm{Ag} / \mathrm{Al}_{2} \mathrm{O}_{3}-\mathrm{OH}$ is shown in Fig. 3. Narrow diffraction peaks appeared at 18.6, 20.3, 27.8, 40.7, 53.1, 57.4, 63.8 and $70.6^{\circ}$ attesting for the formation of a bayerite phase $\left(\mathrm{Al}(\mathrm{OH})_{3}\right)$ when $\mathrm{Al}_{2} \mathrm{O}_{3}$ was submitted to a thermal treatment in water in agreement with earlier reports [14-16], although the experimental conditions used in the present work differed substantially from those of these earlier studies. The XRD pattern of the dried $\mathrm{Ag} / \mathrm{Al}_{2} \mathrm{O}_{3}-\mathrm{OH}$ sample (not shown) was found to be identical to that of the parent $\mathrm{Al}_{2} \mathrm{O}_{3}-\mathrm{OH}$ shown in Fig. 3. After calcination of $\mathrm{Ag} / \mathrm{Al}_{2} \mathrm{O}_{3^{-}}$ $\mathrm{OH}$ at $550{ }^{\circ} \mathrm{C}$, the $\mathrm{XRD}$ pattern closely resembled that of the parent $\mathrm{Al}_{2} \mathrm{O}_{3}$ support suggesting that the bayerite phase likely mainly transformed into $\eta-\mathrm{Al}_{2} \mathrm{O}_{3}$ [20-2122], since the XRD patterns of $\gamma-\mathrm{Al}_{2} \mathrm{O}_{3}$ and $\eta-\mathrm{Al}_{2} \mathrm{O}_{3}$ differ only little from each other [20-22], and probably also transformed back to $\gamma-\mathrm{Al}_{2} \mathrm{O}_{3}$ to a limited extent [20,22]. 
Similar UV-visible spectra were obtained for calcined $\mathrm{Ag} / \mathrm{Al}_{2} \mathrm{O}_{3}$ and $\mathrm{Ag} / \mathrm{Al}_{2} \mathrm{O}_{3}-\mathrm{OH}$ (Fig. 4). Three bands were observed at 210, 240 and $350 \mathrm{~nm}$ on both samples. Whereas the band at $210 \mathrm{~nm}$ has been attributed to $\mathrm{Ag}^{+}[9,23]$, the attribution of those at 240 and $350 \mathrm{~nm}$ are still the subject of controversy. The band at $240 \mathrm{~nm}$ has been assigned to the presence of $\mathrm{Ag}^{+}$[23] and partially charged Ag clusters $\left(\mathrm{Ag}_{\mathrm{n}}{ }^{8+}\right)$ [9], whereas that at $350 \mathrm{~nm}$ has been attributed to the presence of partially charged Ag clusters $\left(\operatorname{Ag}_{n}{ }^{\delta+}\right)[24]$ as well as that of small metallic clusters $\left(\mathrm{Ag}_{\mathrm{n}}\right)$ [9]. Note that the silver plasmon characteristic of $\mathrm{Ag}$ metal particles is usually located above $390 \mathrm{~nm}$ [23]. From these UV-visible results and the fact that $\mathrm{Ag}$ coordination numbers determined earlier by EXAFS were found to remain extremely low under various experimental conditions including those of $\mathrm{H}_{2}$-HC-SCR [25], it can be assumed that $\mathrm{Ag}$ is mainly present in an oxidized state in both samples.

As shown earlier, the characterization of $\mathrm{Ag} / \mathrm{Al}_{2} \mathrm{O}_{3}$ samples by $\mathrm{NO}_{x}$-TPD provided unique information about the coverage of $\mathrm{Al}_{2} \mathrm{O}_{3}$ by $\mathrm{Ag}$ which could not be obtained by other means $[6,8]$. The $\mathrm{NO}_{x}$-TPD profiles obtained for the hydroxylated samples are shown in Fig. 5a. For comparison, those obtained earlier [6] on $\mathrm{Al}_{2} \mathrm{O}_{3}$ and $\mathrm{Ag} / \mathrm{Al}_{2} \mathrm{O}_{3}$ are displayed in Fig. 5b. Whereas it can be clearly seen that the introduction of $\mathrm{Ag}$ on $\mathrm{Al}_{2} \mathrm{O}_{3}$ led to both a significant decrease in the $\mathrm{NO}_{x}$ uptake $\left(446 \mu \mathrm{mol} \mathrm{NO} / \mathrm{g}\right.$ for $\mathrm{Al}_{2} \mathrm{O}_{3}$ compared to $337 \mu \mathrm{mol}$ $\mathrm{NO}_{x} / \mathrm{g}_{\mathrm{Al} 2 \mathrm{O} 3}$ for $\left.\mathrm{Ag} / \mathrm{Al}_{2} \mathrm{O}_{3}\right)$ and a shift of the low temperature desorption peak to higher temperatures (Fig. 5b), this was not observed for the hydroxylated samples. Fig. 5a shows that the $\mathrm{NO}_{x}$ profiles of $\mathrm{Ag} / \mathrm{Al}_{2} \mathrm{O}_{3}-\mathrm{OH}$ and $\mathrm{Al}_{2} \mathrm{O}_{3}-\mathrm{OH}$ are similar in shape, albeit slightly different from those found on $\mathrm{Al}_{2} \mathrm{O}_{3}$ (Fig. 5b). In addition the $\mathrm{NO}_{x}$ uptakes determined on the hydroxylated samples were found to be similar for $\mathrm{Al}_{2} \mathrm{O}_{3}-\mathrm{OH}\left(439 \mu\right.$ mol $\mathrm{NO}_{x} / \mathrm{g}$ ) and $\mathrm{Ag} / \mathrm{Al}_{2} \mathrm{O}_{3}-\mathrm{OH}\left(442 \mu \mathrm{mol} \mathrm{NO}_{x} / \mathrm{g}_{\mathrm{Al} 2 \mathrm{O} 3}\right)$ and fairly close to that of $\mathrm{Al}_{2} \mathrm{O}_{3}\left(446 \mu \mathrm{mol} \mathrm{NO}_{x} / \mathrm{g}\right)$. Since the transformation of the bayerite domains likely leads to the formation of $\eta-\mathrm{Al}_{2} \mathrm{O}_{3}[20$ 22], we found of interest to perform an additional $\mathrm{NO}_{x}$-TPD experiment on a $\eta-\mathrm{Al}_{2} \mathrm{O}_{3}$ support 
(SASOL, $314 \mathrm{~m}^{2} / \mathrm{g}$ ) to compare the $\mathrm{NO}_{x}$ adsorption capacity of $\eta-\mathrm{Al}_{2} \mathrm{O}_{3}$ to that of $\gamma-\mathrm{Al}_{2} \mathrm{O}_{3}$. The $\mathrm{NO}_{x}$-TPD profile obtained for $\eta-\mathrm{Al}_{2} \mathrm{O}_{3}$ (not shown) was found to be similar in shape to that obtained earlier on $\gamma-\mathrm{Al}_{2} \mathrm{O}_{3}[6]$, but of higher intensity $\left(761 \mu \mathrm{mol} \mathrm{NO}_{x} / \mathrm{g}\right.$ compared to 446 $\mu \mathrm{mol} \mathrm{NO}_{x} / \mathrm{g}$ for $\gamma-\mathrm{Al}_{2} \mathrm{O}_{3}$ ). Taking into account the specific surface areas of $314 \mathrm{~m}^{2} / \mathrm{g}$ for $\eta$ $\mathrm{Al}_{2} \mathrm{O}_{3}$ and $180 \mathrm{~m}^{2} / \mathrm{g}$ for $\gamma-\mathrm{Al}_{2} \mathrm{O}_{3}$, the amounts of $\mathrm{NO}_{x}$ adsorbed normalized per unit surface area $\left(\mathrm{NO}_{x}\right.$ surface density) are found to be very close on both polymorphs (2.4 and $2.5 \mu \mathrm{mol}$ $\mathrm{NO}_{x} / \mathrm{m}^{2}$ on $\eta$ - and $\gamma$-alumina, respectively). Zecchina and co-workers [28] also found that the total amounts of $\mathrm{NO}_{x}$ adsorbed from $\mathrm{NO}_{2}$ on $\gamma$ - and $\delta$ - $\mathrm{Al}_{2} \mathrm{O}_{3}$ correlated with the specific surface areas of both polymorphs, indicating, in other words, that the $\mathrm{NO}_{x}$ surface density of alumina was unaffected by the nature of its polymorph.

\section{Discussion}

The treatment of the pristine $\mathrm{Al}_{2} \mathrm{O}_{3}$ support in water at $80{ }^{\circ} \mathrm{C}$ for $24 \mathrm{~h}$ prior to $\mathrm{Ag}$ deposition led to a drastic improvement of the low-temperature $\mathrm{H}_{2}-\mathrm{C}_{3} \mathrm{H}_{6}-\mathrm{SCR}\left(\mathrm{Ag} / \mathrm{Al}_{2} \mathrm{O}_{3}-\mathrm{OH}\right)$ performance compared to the $\mathrm{Ag} / \mathrm{Al}_{2} \mathrm{O}_{3}$ sample prepared on the as-received $\mathrm{Al}_{2} \mathrm{O}_{3}$ support (Fig. 2a). In contrast, the $\mathrm{C}_{3} \mathrm{H}_{6}$-SCR performance was found to be comparable on both samples and was thus found not to be influenced to a significant extent by a prior thermal treatment in water of the alumina support (Fig. 1a).

XRD characterization showed that the thermal pretreatment in water led to the hydroxylation of $\mathrm{Al}_{2} \mathrm{O}_{3}$ with the appearance of reflections attributed to the formation of a bayerite phase $\left(\mathrm{Al}(\mathrm{OH})_{3}\right.$, Fig. 3). The fact that the XRD patterns of $\mathrm{Al}_{2} \mathrm{O}_{3}-\mathrm{OH}$ and $\mathrm{Ag} / \mathrm{Al}_{2} \mathrm{O}_{3^{-}}$ $\mathrm{OH}$ in their calcined state closely resembled those of $\gamma-\mathrm{Al}_{2} \mathrm{O}_{3}$ and $\mathrm{Ag} / \gamma-\mathrm{Al}_{2} \mathrm{O}_{3}$ indicates that the bayerite phase likely transformed to $\eta-\mathrm{Al}_{2} \mathrm{O}_{3}$ and $\gamma-\mathrm{Al}_{2} \mathrm{O}_{3}$ after calcination at $550{ }^{\circ} \mathrm{C}$. The extent of transformation of the bayerite domains to $\eta-\mathrm{Al}_{2} \mathrm{O}_{3}$ and $\gamma-\mathrm{Al}_{2} \mathrm{O}_{3}$ could not be quantified as the $\eta-\mathrm{Al}_{2} \mathrm{O}_{3}$ and $\gamma-\mathrm{Al}_{2} \mathrm{O}_{3}$ XRD patterns are only subtlety different from each 
other [20-22] and that complete conversion of $\gamma-\mathrm{Al}_{2} \mathrm{O}_{3}$ to bayerite did not occur (Fig. 3). The UV-visible characterization of calcined $\mathrm{Al}_{2} \mathrm{O}_{3}-\mathrm{OH}$ and $\mathrm{Ag} / \mathrm{Al}_{2} \mathrm{O}_{3}-\mathrm{OH}$ indicated that their $\mathrm{Ag}$ speciation was comparable (Fig. 4). Much more interesting is the characterization of the various samples by $\mathrm{NO}_{x}$-TPD. We reported earlier [6] that the addition of $\mathrm{Ag}$ to $\mathrm{Al}_{2} \mathrm{O}_{3}$ led to a decrease in the $\mathrm{NO}_{x}$ uptake (Fig. 5b) and concluded that $\mathrm{Ag}$ occupied some of the $\mathrm{Al}_{2} \mathrm{O}_{3}$ sites responsible for $\mathrm{NO}_{x}$ adsorption (Scheme 1, Path A). It must be recalled that the $\mathrm{NO}_{x}$ adsorption sites of partly dehydroxylated $\mathrm{Al}_{2} \mathrm{O}_{3}$ samples have been attributed to $\mathrm{Al}^{3+}[26,27]$, $\mathrm{O}^{2-}[27,28]$ and $\mathrm{OH}$ [27] groups. In the case of the samples prepared from hydroxylated $\mathrm{Al}_{2} \mathrm{O}_{3}$, the situation is clearly different as the $\mathrm{NO}_{x}$ uptakes of $\mathrm{Al}_{2} \mathrm{O}_{3}-\mathrm{OH}$ and $\mathrm{Ag} / \mathrm{Al}_{2} \mathrm{O}_{3}-\mathrm{OH}$ remained close to that found on $\mathrm{Al}_{2} \mathrm{O}_{3}$ (Fig. 5a and section 3.2.). The higher $\mathrm{NO}_{x}$ uptake of $\mathrm{Ag} / \mathrm{Al}_{2} \mathrm{O}_{3}-\mathrm{OH}$ compared to that of $\mathrm{Ag} / \mathrm{Al}_{2} \mathrm{O}_{3}$ (Fig. 5a) cannot be attributed to the likely presence of $\eta-\mathrm{Al}_{2} \mathrm{O}_{3}$ domains issued from the transformation of the bayerite ones since it was found that the specific surface area of both samples did not change significantly (section 2.3.) and that the $\mathrm{NO}_{x}$ surface density of $\eta-\mathrm{Al}_{2} \mathrm{O}_{3}$ and $\gamma-\mathrm{Al}_{2} \mathrm{O}_{3}$ was similar (end of section 3.2.). For $\mathrm{Ag} / \mathrm{Al}_{2} \mathrm{O}_{3}-\mathrm{OH}$, it can therefore be concluded that $\mathrm{Ag}$ anchored essentially onto sites newlycreated by the thermal pretreatment of $\gamma-\mathrm{Al}_{2} \mathrm{O}_{3}$ in water, which were not available on the untreated support as illustrated in Scheme 1 (Path B), thus leaving the sites present initially on $\gamma-\mathrm{Al}_{2} \mathrm{O}_{3}$ accessible to the adsorption of $\mathrm{NO}_{x}$. This newly-created sites most likely belong to the bayerite domains formed by thermal pretreatment in water of $\gamma-\mathrm{Al}_{2} \mathrm{O}_{3}$ as indicated by XRD (Fig. 3).

In a recent investigation, we showed that $\mathrm{H}_{2}-\mathrm{C}_{3} \mathrm{H}_{6}-\mathrm{SCR}$ performance unexpectedly decreased as the $\mathrm{Ag}$ surface density $\left(\mathrm{Ag} / \mathrm{nm}^{2}{ }_{\mathrm{Al} 2 \mathrm{O} 3}\right)$ increased [8]. The $\mathrm{H}_{2}-\mathrm{C}_{3} \mathrm{H}_{6}$-SCR kinetic study highlighted the importance of the $\mathrm{NO}_{x}$ coverage in this reaction, based on structureactivity $\left(\mathrm{NO}_{x}\right.$ uptake-kinetic parameters) correlations. In particular, the increase in the NO reaction order from 0 for $\mathrm{C}_{3} \mathrm{H}_{6}-\mathrm{SCR}$ to 0.4 for $\mathrm{H}_{2}-\mathrm{C}_{3} \mathrm{H}_{6}-\mathrm{SCR}$ on $\mathrm{Ag}\left(0.7 \mathrm{Ag} / \mathrm{nm}^{2}{ }_{\mathrm{Al} 2 \mathrm{O} 3}\right) / \mathrm{Al}_{2} \mathrm{O}_{3}$ 
was assigned to a depletion in the coverage of $\mathrm{NO}_{x}$ adsorbed species due to a drastic increase in the $\mathrm{H}_{2}-\mathrm{C}_{3} \mathrm{H}_{6}-\mathrm{SCR}$ reaction rate compared to that of $\mathrm{C}_{3} \mathrm{H}_{6}-\mathrm{SCR}$ [8]. Likewise, the decrease in $\mathrm{H}_{2}-\mathrm{C}_{3} \mathrm{H}_{6}-\mathrm{SCR}$ catalytic performance observed as the Ag surface density increased was attributed to a decrease in the $\mathrm{NO}_{x}$ coverage due to the anchoring of $\mathrm{Ag}$ species onto $\mathrm{Al}_{2} \mathrm{O}_{3}$ sites also responsible for $\mathrm{NO}_{x}$ adsorption, in agreement with the observed decrease in $\mathrm{NO}_{x}$ uptake [8]. As indicated by the $\mathrm{NO}_{x}$-TPD characterization of the samples studied in the present work (Fig. 5), the $\mathrm{NO}_{x}$ uptake found on $\mathrm{Ag} / \mathrm{Al}_{2} \mathrm{O}_{3}-\mathrm{OH}$ remained close to that of $\mathrm{Al}_{2} \mathrm{O}_{3}$ and $\mathrm{Al}_{2} \mathrm{O}_{3}-\mathrm{OH}$ but much larger than that of $\mathrm{Ag} / \mathrm{Al}_{2} \mathrm{O}_{3}$. This suggests that $\mathrm{NO}_{x}$ coverage on $\mathrm{Ag} / \mathrm{Al}_{2} \mathrm{O}_{3}-\mathrm{OH}$ would be higher than that on $\mathrm{Ag} / \mathrm{Al}_{2} \mathrm{O}_{3}$ despite the fact that their surface areas were found to be similar for both samples (section 2.3.). The higher $\mathrm{NO}_{x}$ coverage on $\mathrm{Ag} / \mathrm{Al}_{2} \mathrm{O}_{3}-\mathrm{OH}$ compared with $\mathrm{Ag} / \mathrm{Al}_{2} \mathrm{O}_{3}$ could thus account for the much higher $\mathrm{H}_{2}-\mathrm{C}_{3} \mathrm{H}_{6^{-}}$ SCR performance found on $\mathrm{Ag} / \mathrm{Al}_{2} \mathrm{O}_{3}-\mathrm{OH}$ compared to $\mathrm{Ag} / \mathrm{Al}_{2} \mathrm{O}_{3}$ (Fig. 2a). In the absence of $\mathrm{H}_{2}$ in the reacting feed, the similar $\mathrm{C}_{3} \mathrm{H}_{6}$-SCR performance found on both Ag samples (Fig. 1a) is consistent with the absence of NO partial pressure dependency $\left(0^{\text {th }}\right.$ reaction order with respect to $\mathrm{NO}$ for $\mathrm{C}_{3} \mathrm{H}_{6}$-SCR [8]) and thus with the absence of $\mathrm{NO}_{x}$ coverage dependency for the $\mathrm{C}_{3} \mathrm{H}_{6}$-SCR reaction. The close $\mathrm{C}_{3} \mathrm{H}_{6}$-SCR performance obtained on $\mathrm{Ag} / \mathrm{Al}_{2} \mathrm{O}_{3}-\mathrm{OH}$ and $\mathrm{Ag} / \mathrm{Al}_{2} \mathrm{O}_{3}$ (Fig. 1a) is also consistent with the fact that the $\mathrm{Ag}$ speciation on both samples was found to be similar as indicated by UV-visible characterization (Fig. 4).

Although it is widely acknowledged in the community that the starting supporting oxide/oxyhydroxide is of the utmost importance for the $\mathrm{Ag} / \mathrm{Al}_{2} \mathrm{O}_{3}$ system, studies in which the SCR performance of $\mathrm{Ag} / \mathrm{Al}_{2} \mathrm{O}_{3}$ was compared within samples synthesized under identical conditions from various supporting oxide/oxyhydroxides $\left(\mathrm{Al}_{2} \mathrm{O}_{3}, \mathrm{AlOOH}, \mathrm{Al}(\mathrm{OH})_{3}\right)$ are rare. To our knowledge, only two studies have been reported to date in which the influence of the starting support was investigated [13,29]. Although calcination of the oxyhydroxides supports eventually leads to $\mathrm{Al}_{2} \mathrm{O}_{3}$, from here on the samples studied in these earlier works will be 
denoted as Ag/starting oxide/oxyhydroxides for the sake of clarity. Zhang and Kaliaguine reported that $\mathrm{Ag} / \mathrm{AlOOH}$ exhibited the best $\mathrm{C}_{3} \mathrm{H}_{6}-\mathrm{SCR}$ performance compared to $\mathrm{Ag} / \mathrm{Al}_{2} \mathrm{O}_{3}$ and $\mathrm{Ag} / \mathrm{Al}(\mathrm{OH})_{3}[13]$. Regarding $\mathrm{Ag} / \mathrm{Al}(\mathrm{OH})_{3}$, (i) its very low surface area, leading to a silver density (3.1 Ag/nm $\left.{ }^{2}{ }_{\text {Il2O3 }}\right)$ well above the optimum $\mathrm{Ag}$ density highlighted recently (0.7 $\left.\mathrm{Ag} / \mathrm{nm}^{2}{ }_{\mathrm{Al} 2 \mathrm{O} 3},[6]\right)$ and (ii) the presence of a significant amount of carbonates prevented a fair comparison of its $\mathrm{C}_{3} \mathrm{H}_{6}$-SCR performance with that of the two other samples. In contrast $\mathrm{Ag} / \mathrm{Al}_{2} \mathrm{O}_{3}$ and $\mathrm{Ag} / \mathrm{AlOOH}$ exhibited comparable specific surface areas $\left(\sim 140 \mathrm{~m}^{2} / \mathrm{g}\right)$ and thus we could calculate that their Ag surface densities were similar and close to $0.8 \mathrm{Ag} / \mathrm{nm}^{2}{ }_{\mathrm{Al} 2 \mathrm{O} 3}$. The higher $\mathrm{C}_{3} \mathrm{H}_{6}$-SCR performance of $\mathrm{Ag} / \mathrm{AlOOH}$ compared to that of $\mathrm{Ag} / \mathrm{Al}_{2} \mathrm{O}_{3}$ was attributed by Zhang and Kaliaguine to the higher dispersion of $\mathrm{Ag}$ on $\mathrm{AlOOH}$ due to the greater concentration of $\mathrm{OH}$ groups in $\mathrm{AlOOH}$ compared to $\mathrm{Al}_{2} \mathrm{O}_{3}$ [13]. In addition, Zhang and Kaliaguine showed that $\mathrm{Ag}$ was present in a more oxidized state on $\mathrm{Ag} / \mathrm{AlOOH}$ than on $\mathrm{Ag} / \mathrm{Al}_{2} \mathrm{O}_{3}$ [13]. It must be recalled here that oxidized $\mathrm{Ag}$ species have been reported to be the active sites of HC-SCR promoted or not by $\mathrm{H}_{2}[1,7,9,24-31]$. As indicated by the UV-visible data of the present study (Fig. 4), Ag speciation was found to be comparable for our $\mathrm{Ag} / \mathrm{Al}_{2} \mathrm{O}_{3}-\mathrm{OH}$ and $\mathrm{Ag} / \mathrm{Al}_{2} \mathrm{O}_{3}$ samples suggesting similar dispersion, so that it is not surprising that both catalysts eventually exhibited close $\mathrm{C}_{3} \mathrm{H}_{6}$-SCR performance (Fig. 1a).

In a recent study, $\mathrm{He}$ and co-workers reported on the superiority of $\mathrm{Ag} / \mathrm{AlOOH}$ compared to $\mathrm{Ag} / \mathrm{Al}_{2} \mathrm{O}_{3}$ and $\mathrm{Ag} / \mathrm{Al}(\mathrm{OH})_{3}$ in $\mathrm{C}_{2} \mathrm{H}_{5} \mathrm{OH}-\mathrm{SCR}$ after calcination of the samples at $600{ }^{\circ} \mathrm{C}$ [29]. These authors suggested that the $\mathrm{C}_{2} \mathrm{H}_{5} \mathrm{OH}-\mathrm{SCR}$ activity was correlated to the amount of tetrahedrally-coordinated $\mathrm{Al}^{3+}$ cations supposed to be the active sites of the adsorption and activation of the -NCO intermediates [29]. Toops and co-workers initially proposed that atomic hydrogen may be formed on the surface of a $\mathrm{Ag} / \mathrm{Al}_{2} \mathrm{O}_{3}$ catalyst under a $\mathrm{C}_{2} \mathrm{H}_{5} \mathrm{OH}-\mathrm{SCR}$ feed via the dissociative adsorption of ethanol [32]. The presence of molecular $\mathrm{H}_{2}$ has been recently detected in the course of methanol-assisted HC-SCR [33] and methanol- 
SCR [34,35] reactions. This led these authors [33-35] to the proposal that the high SCR performance found at low-temperature in the presence of alcohols was due, at least partly, to a similar effect as that of $\mathrm{H}_{2}$ in $\mathrm{H}_{2}$-HC-SCR [8]. According to the results of the present study, in which it is proposed that the higher $\mathrm{H}_{2}-\mathrm{C}_{3} \mathrm{H}_{6}-\mathrm{SCR}$ performance of $\mathrm{Ag} / \mathrm{Al}_{2} \mathrm{O}_{3}-\mathrm{OH}$ compared to $\mathrm{Ag} / \mathrm{Al}_{2} \mathrm{O}_{3}$ would be attributed to the higher $\mathrm{NO}_{x}$ coverage on $\mathrm{Ag} / \mathrm{Al}_{2} \mathrm{O}_{3}-\mathrm{OH}$ due to the preferential interaction of $\mathrm{Ag}$ with newly created $\mathrm{OH}$ groups, the higher $\mathrm{C}_{2} \mathrm{H}_{5} \mathrm{OH}-\mathrm{SCR}$ performance of $\mathrm{Ag} / \mathrm{AlOOH}$ compared to $\mathrm{Ag} / \mathrm{Al}_{2} \mathrm{O}_{3}$ reported in [29] could be accounted for by a similar reason. Ag anchoring on $\mathrm{AlOOH}$ sites different from those of $\mathrm{Al}_{2} \mathrm{O}_{3}$ would help preserve a higher $\mathrm{NO}_{x}$ density in the final catalyst as shown in the present work. This explanation, however, cannot stand as the only reason to describe the order of $\mathrm{C}_{2} \mathrm{H}_{5} \mathrm{OH}-\mathrm{SCR}$ activity found by $\mathrm{He}$ and co-workers [29]: $\mathrm{Ag} / \mathrm{AlOOH}>\mathrm{Ag} / \mathrm{Al}_{2} \mathrm{O}_{3}>\mathrm{Ag} / \mathrm{Al}(\mathrm{OH})_{3}$. $\mathrm{Ag} / \mathrm{Al}(\mathrm{OH})_{3}$ was found to exhibit the lowest $\mathrm{C}_{2} \mathrm{H}_{5} \mathrm{OH}-\mathrm{SCR}$ performance among the samples investigated indeed, whereas it could have been expected that this particular catalyst should have provided a catalytic performance at least higher than that of $\mathrm{Ag} / \mathrm{Al}_{2} \mathrm{O}_{3}$ on the sole basis of the conclusions drawn in our present work. As highlighted above, the $\mathrm{C}_{2} \mathrm{H}_{5} \mathrm{OH}-\mathrm{SCR}$ reaction must behave closer to $\mathrm{H}_{2}$-HC-SCR than to HC-SCR [33-35] and we have reported recently that the performance of $\mathrm{Ag} / \mathrm{Al}_{2} \mathrm{O}_{3}$ catalysts increased as the $\mathrm{Ag}$ loading, i.e. $\mathrm{Ag}$ surface density, decreased in $\mathrm{H}_{2}-\mathrm{C}_{3} \mathrm{H}_{6}$-SCR [8]. This is consistent with the fact that $\mathrm{Ag} / \mathrm{Al}_{2} \mathrm{O}_{3}$ samples with $\mathrm{Ag}$ contents lower than $2 \mathrm{wt} \%$ were found to be more active in $\mathrm{C}_{2} \mathrm{H}_{5} \mathrm{OH}-\mathrm{SCR}$ than the $\operatorname{Ag}(2 \mathrm{wt} \%) / \mathrm{Al}_{2} \mathrm{O}_{3}$ sample [36,37]; $\mathrm{Ag}(2 \mathrm{wt} \%) / \mathrm{Al}_{2} \mathrm{O}_{3}$ has been reported to be the optimum catalyst in HC-SCR [6] but not in $\mathrm{H}_{2}$-HC-SCR [8] indeed. In the work of He and coworkers, the surface areas of $\mathrm{Ag} / \mathrm{AlOOH}\left(213.1 \mathrm{~m}^{2} / \mathrm{g}\right), \mathrm{Ag}_{\mathrm{Al}} \mathrm{O}_{3}\left(197.9 \mathrm{~m}^{2} / \mathrm{g}\right)$ and $\mathrm{Ag} / \mathrm{Al}(\mathrm{OH})_{3}\left(168.1 \mathrm{~m}^{2} / \mathrm{g}\right)$ were found to be substantially different after calcination at $600{ }^{\circ} \mathrm{C}$ [29]. The order of activity reported for these catalysts in $\mathrm{C}_{2} \mathrm{H}_{5} \mathrm{OH}-\mathrm{SCR}(\mathrm{Ag} / \mathrm{AlOOH}>$ $\left.\mathrm{Ag} / \mathrm{Al}_{2} \mathrm{O}_{3}>\mathrm{Ag} / \mathrm{Al}(\mathrm{OH})_{3}\right)$ also follows the order expected from the calculated $\mathrm{Ag}$ surface 
densities of the corresponding samples $\left(\mathrm{Ag} / \mathrm{AlOOH}: 0.5 \mathrm{Ag} / \mathrm{nm}^{2}{ }_{\mathrm{Al} 2 \mathrm{O} 3}<\mathrm{Ag} / \mathrm{Al}_{2} \mathrm{O}_{3}: 0.6\right.$ $\left.\mathrm{Ag} / \mathrm{nm}^{2}{ }_{\mathrm{Al} 2 \mathrm{O} 3}<\mathrm{Ag} / \mathrm{Al}(\mathrm{OH})_{3}: 0.7 \mathrm{Ag} / \mathrm{nm}^{2}{ }_{\mathrm{Al} 2 \mathrm{O} 3}\right)$. To summarize, in addition to the potential involvement of tetrahedrally-coordinated $\mathrm{Al}^{3+}$ cations in $\mathrm{C}_{2} \mathrm{H}_{5} \mathrm{OH}-\mathrm{SCR}$ [29], the superiority of the $\mathrm{Ag} / \mathrm{AlOOH}$ catalyst compared to $\mathrm{Ag} / \mathrm{Al}_{2} \mathrm{O}_{3}$ and $\mathrm{Ag} / \mathrm{Al}(\mathrm{OH})_{3}$ in $\mathrm{C}_{2} \mathrm{H}_{5} \mathrm{OH}-\mathrm{SCR}$ reported in [29] may also result from differences in the $\mathrm{NO}_{x}$ coverage on the corresponding samples influenced by (i) the preferential interaction of $\mathrm{Ag}$ with $\mathrm{AlOOH}$ anchoring sites different from those found on $\mathrm{Al}_{2} \mathrm{O}_{3}$, as highlighted in the present work, and/or (ii) the Ag surface density of the samples [8].

\section{Conclusion}

This work highlights for the first time that a thermal treatment in water of $\gamma-\mathrm{Al}_{2} \mathrm{O}_{3}$ prior to $\mathrm{Ag}$ deposition leads to a drastic enhancement of $\mathrm{H}_{2}-\mathrm{C}_{3} \mathrm{H}_{6}-\mathrm{SCR}$ performance at low temperature. Based on an earlier $\mathrm{H}_{2}-\mathrm{C}_{3} \mathrm{H}_{6}$-SCR kinetic investigation [8] and on the $\mathrm{NO}_{x}$ uptake data, this improvement is attributed to the higher $\mathrm{NO}_{x}$ coverage on $\mathrm{Ag} / \mathrm{Al}_{2} \mathrm{O}_{3}-\mathrm{OH}$ compared with $\mathrm{Ag} / \mathrm{Al}_{2} \mathrm{O}_{3}$. The higher $\mathrm{NO}_{x}$ adsorption capacity of $\mathrm{Ag} / \mathrm{Al}_{2} \mathrm{O}_{3}$ prepared from the $\gamma-\mathrm{Al}_{2} \mathrm{O}_{3}$ support thermally-pretreated in water is proposed to result from the preferential interaction of $\mathrm{Ag}$ with newly-created $\mathrm{Al}_{2} \mathrm{O}_{3}$ anchoring sites $\left(\mathrm{Al}(\mathrm{OH})_{3}\right.$ bayerite domains), which were not available on the untreated pristine support. The identification of the latter sites is currently being investigated. The present work may also provide arguments on the fact that boehmite $(\mathrm{AlOOH})$ is known to be a preferred starting $\mathrm{Al}_{2} \mathrm{O}_{3}$ precursor for the preparation of $\mathrm{Ag} / \mathrm{Al}_{2} \mathrm{O}_{3}$ catalysts in the $\mathrm{HC}-\mathrm{SCR}$ field, as however scarcely discussed in the corresponding literature.

\section{Acknowledgments}


Dr. T. Chaieb gratefully acknowledges UPMC for financial support (PhD Grant 322/2012). The authors also thank Prof. $\mathrm{X}$. Carrier for providing the $\eta-\mathrm{Al}_{2} \mathrm{O}_{3}$ (SASOL) support and Dr. S. Boujday for fruitful discussions. 


\section{Figure Captions}

Fig. 1. (a) Conversion of $\mathrm{NO}_{x}$ to $\mathrm{N}_{2}$ (solid lines) and selectivity to $\mathrm{N}_{2}$ (dashed lines), and (b) conversion of $\mathrm{C}_{3} \mathrm{H}_{6}$ to $\mathrm{CO}_{x}$ in the $\mathrm{C}_{3} \mathrm{H}_{6}$-SCR reaction on $\mathrm{Ag} / \mathrm{Al}_{2} \mathrm{O}_{3}$ (grey) and $\mathrm{Ag} / \mathrm{Al}_{2} \mathrm{O}_{3}-\mathrm{OH}$ (black). For comparison, the data obtained previously on a different batch of $\mathrm{Ag} / \mathrm{Al}_{2} \mathrm{O}_{3}$ sample [6] are also reported $(\bigcirc, \mathrm{O}) .0 .18 \mathrm{~g}$ of $\mathrm{Ag} / \mathrm{Al}_{2} \mathrm{O}_{3}$ in $0.18 \mathrm{~g}$ of $\mathrm{Al}_{2} \mathrm{O}_{3}$. Feed composition: 385 ppm $\mathrm{NO}_{x}, 400$ ppm $\mathrm{C}_{3} \mathrm{H}_{6}, 8 \% \mathrm{O}_{2}$ and He balance with a $230 \mathrm{~mL}$ NTP $/ \mathrm{min}$ flow rate.

Fig. 2. (a) Conversion of $\mathrm{NO}_{x}$ to $\mathrm{N}_{2}$ (solid lines) and selectivity to $\mathrm{N}_{2}$ (dashed lines), and (b) conversions of $\mathrm{C}_{3} \mathrm{H}_{6}$ to $\mathrm{CO}_{x}$ (solid lines), and $\mathrm{H}_{2}$ (dotted lines) in the $\mathrm{H}_{2}-\mathrm{C}_{3} \mathrm{H}_{6}$-SCR reaction on $\mathrm{Ag} / \mathrm{Al}_{2} \mathrm{O}_{3}$ (grey) and $\mathrm{Ag} / \mathrm{Al}_{2} \mathrm{O}_{3}-\mathrm{OH}$ (black). For comparison, the data obtained previously on a different batch of $\mathrm{Ag} / \mathrm{Al}_{2} \mathrm{O}_{3}$ sample [8] are also reported $(\bullet, \bigcirc) .0 .18 \mathrm{~g}$ of $\mathrm{Ag} / \mathrm{Al}_{2} \mathrm{O}_{3}$ in $0.18 \mathrm{~g}$ of $\mathrm{Al}_{2} \mathrm{O}_{3}$. Feed composition: $0.21 \% \mathrm{H}_{2}, 385$ ppm $\mathrm{NO}_{x}, 400$ ppm $\mathrm{C}_{3} \mathrm{H}_{6}, 8 \% \mathrm{O}_{2}$ and $\mathrm{He}$ balance with a $230 \mathrm{~mL} \mathrm{NTP}_{\mathrm{N}} / \mathrm{min}$ flow rate.

Fig. 3. XRD patterns of $\mathrm{Al}_{2} \mathrm{O}_{3}$ calcined for $2 \mathrm{~h}$ at $550{ }^{\circ} \mathrm{C}, \mathrm{Al}_{2} \mathrm{O}_{3}-\mathrm{OH}$ dried at $120{ }^{\circ} \mathrm{C}$ for $12 \mathrm{~h}$ and $\mathrm{Ag} / \mathrm{Al}_{2} \mathrm{O}_{3}-\mathrm{OH}$ dried at $120{ }^{\circ} \mathrm{C}$ for $12 \mathrm{~h}$ and calcined for $2 \mathrm{~h}$ at $550{ }^{\circ} \mathrm{C}$. $\mathrm{Al}_{2} \mathrm{O}_{3}$ (JCPDS 791558), Bayerite (JCPDS 20-11).

Fig. 4. $\mathrm{UV}$-vis spectra of $\mathrm{Ag} / \mathrm{Al}_{2} \mathrm{O}_{3}-\mathrm{OH}$ (black) and $\mathrm{Ag} / \mathrm{Al}_{2} \mathrm{O}_{3}$ (grey) after calcination at 550 ${ }^{\circ} \mathrm{C}$ for $2 \mathrm{~h}$. 
Fig. 5. $\mathrm{NO}_{x}$-TPD profiles on (a) $\mathrm{Al}_{2} \mathrm{O}_{3}-\mathrm{OH}\left(-\mathrm{O}_{-}\right)$and $\mathrm{Ag} / \mathrm{Al}_{2} \mathrm{O}_{3}-\mathrm{OH}$ and (b) $\mathrm{Al}_{2} \mathrm{O}_{3}$ (-O-) and $\mathrm{Ag} / \mathrm{Al}_{2} \mathrm{O}_{3}$ [6] after exposure of $0.18 \mathrm{~g}$ of sample to $385 \mathrm{ppm} \mathrm{NO}_{x}$ and $8 \% \mathrm{O}_{2}$ in $\mathrm{He}(230$ $\mathrm{mL}_{\mathrm{NTP}} / \mathrm{min}$ flow rate) at $\mathrm{RT}$ for about $4 \mathrm{~h}$.

Scheme 1. Simplified representation of the influence of the hydroxylation process of $\mathrm{Al}_{2} \mathrm{O}_{3}$ on the deposition of $\mathrm{Ag}$ species $(\bigcirc)$, and the distribution of the $\mathrm{NO}_{x}$ species adsorbed on thermally-treated $(\Delta) \mathrm{Al}_{2} \mathrm{O}_{3}$ surfaces starting from the as-received $\mathrm{Al}_{2} \mathrm{O}_{3}$ (path (A)) and $\mathrm{Al}_{2} \mathrm{O}_{3}-\mathrm{OH}$ (path (B)). 

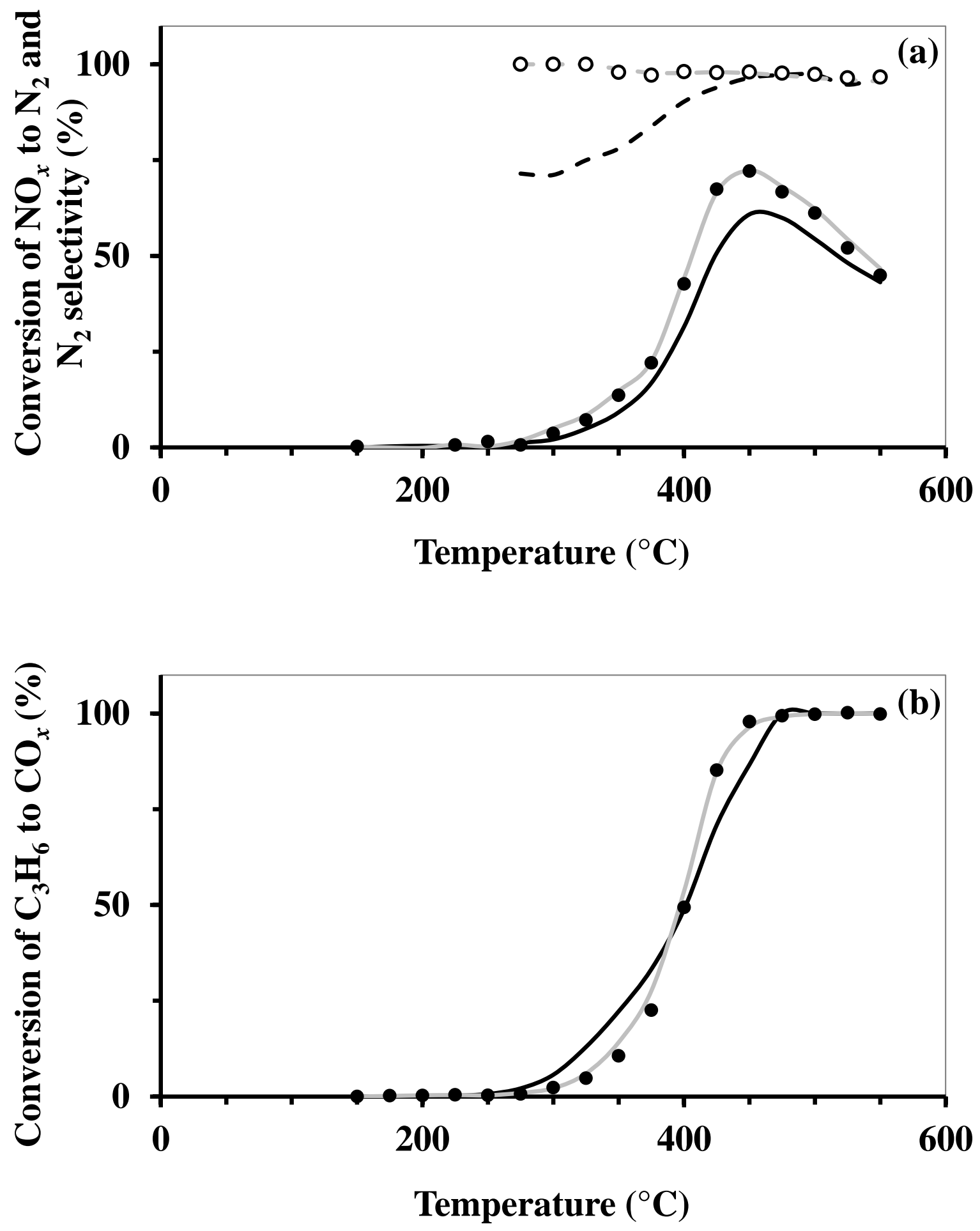

Fig. 1 

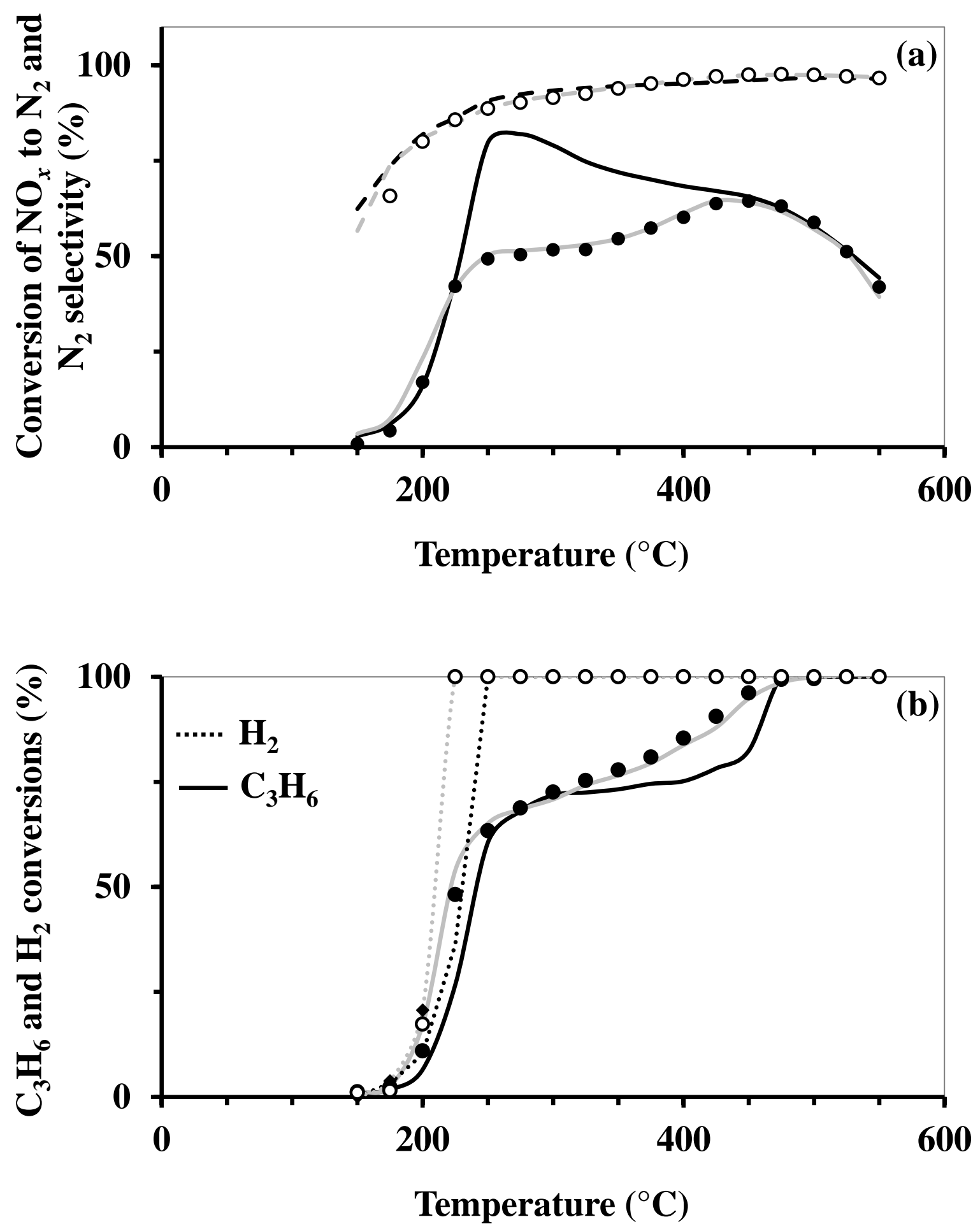

Fig. 2 


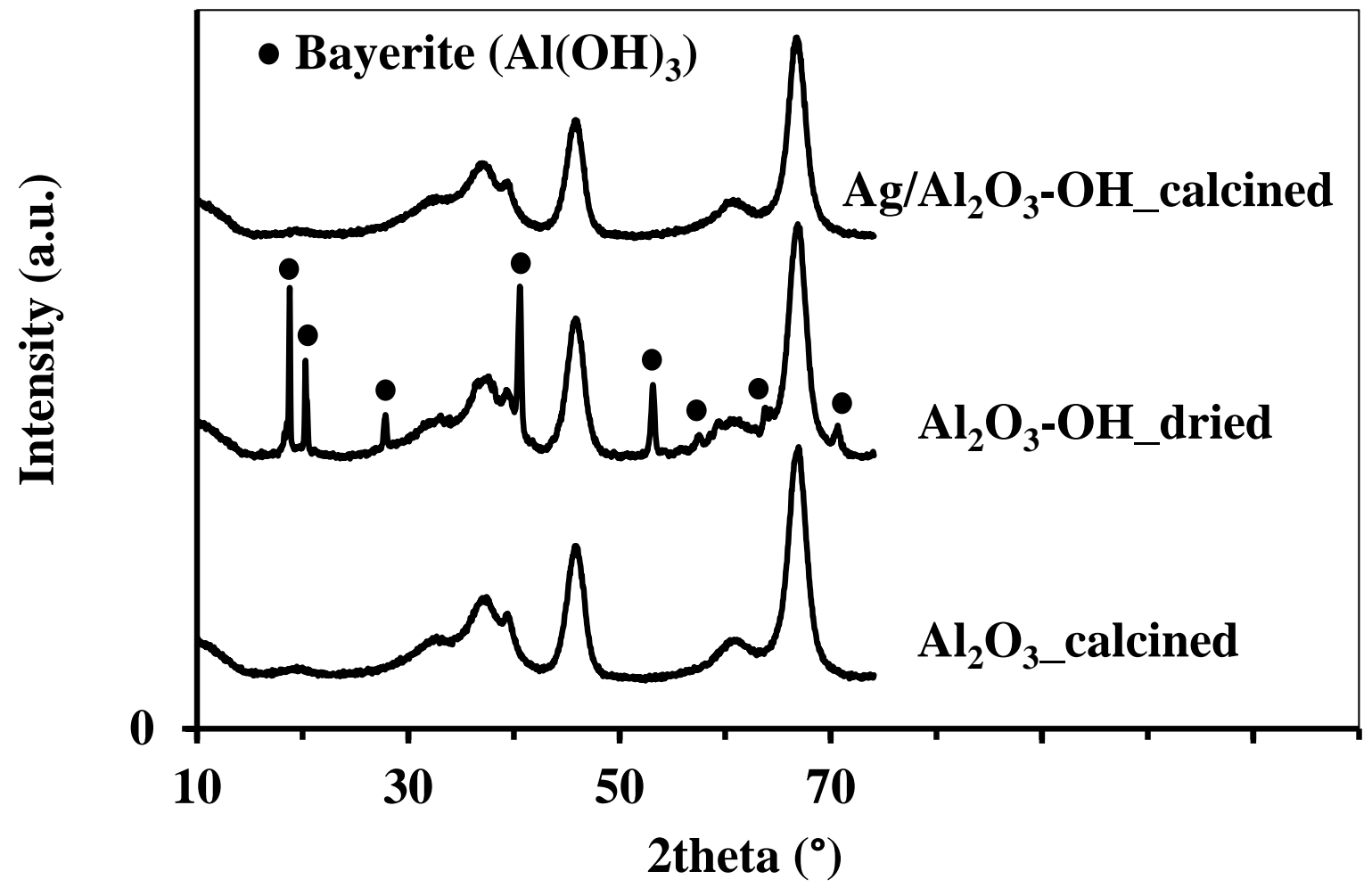

Fig. 3 


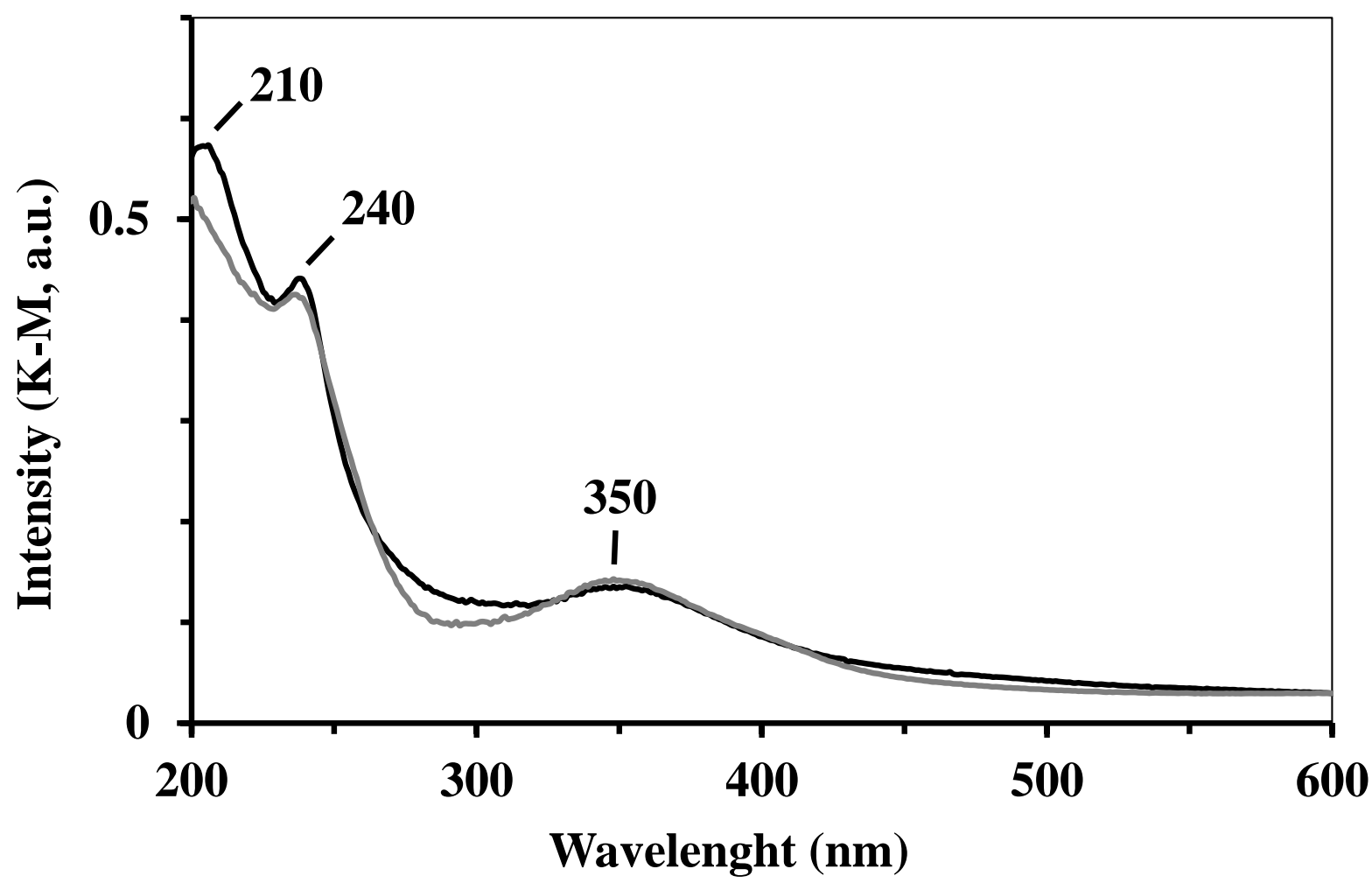

Fig. 4 

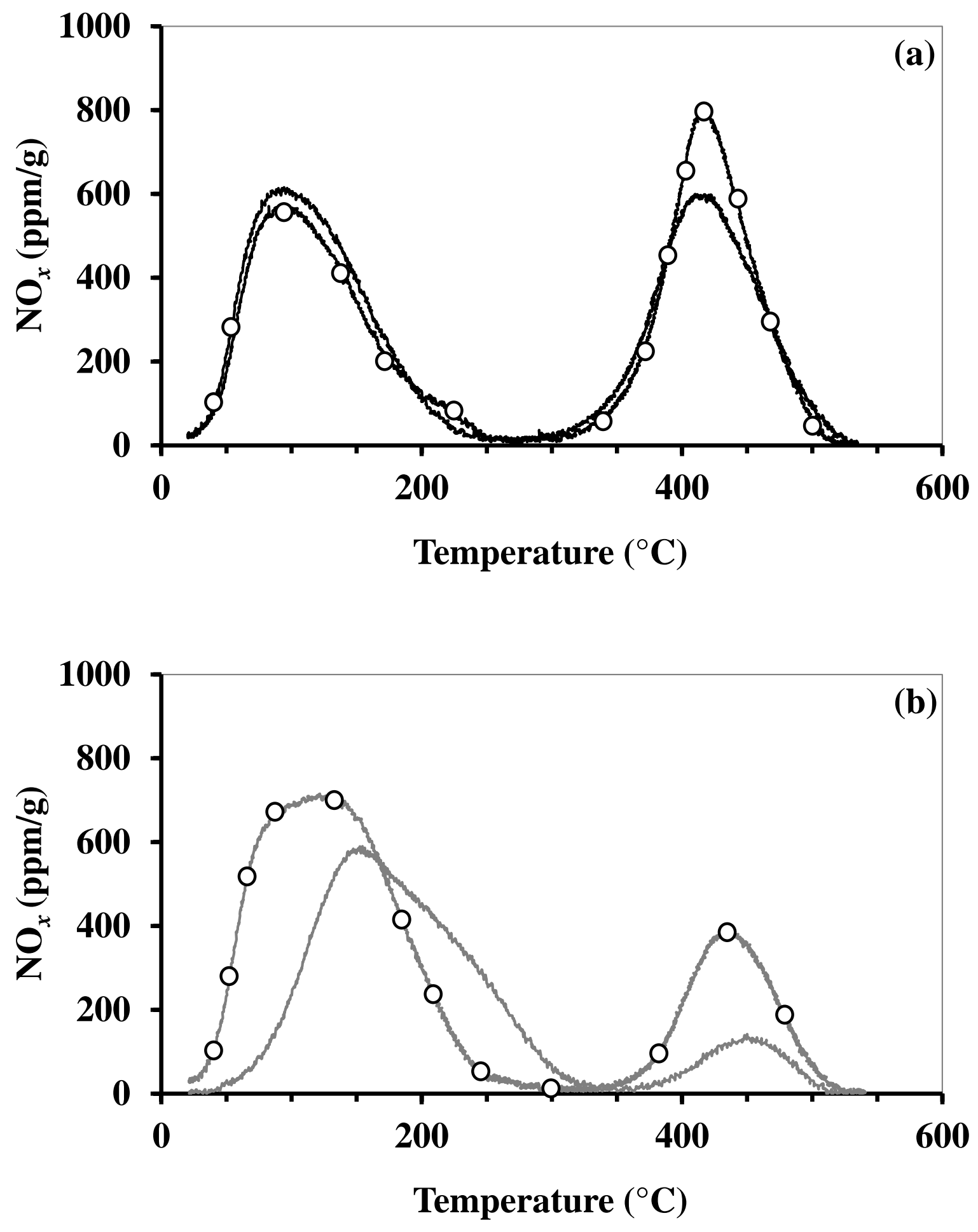

Fig. 5 


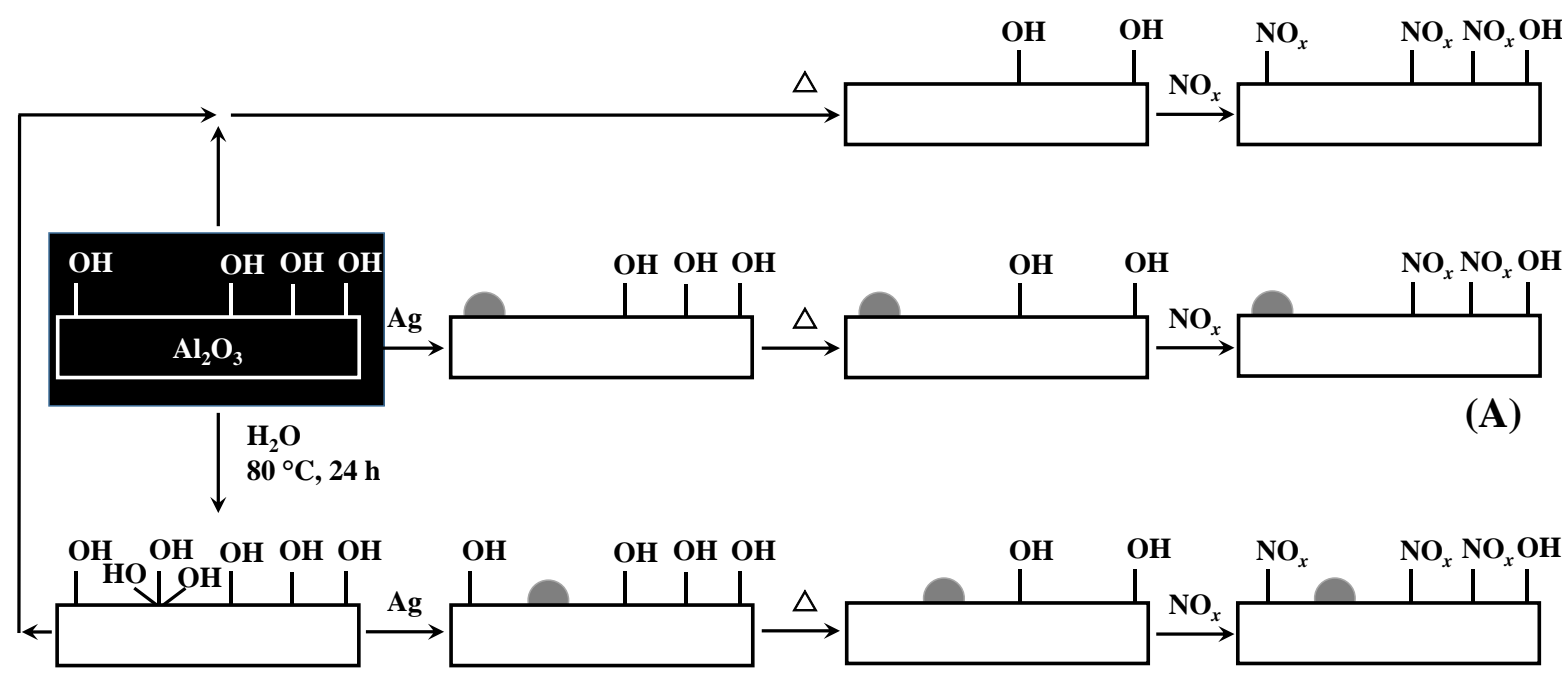

(B)

Scheme 1. 


\section{References}

[1] Burch R (2004) Catal. Rev. Sci. Eng. 46:271.

[2] Epling B, Peden C, Nova I (2014) Catal. Today 231:1.

[3] Miyadera T (1993) Appl. Catal. B 2:199.

[4] Satokawa S (2000) Chem. Lett. 29:294.

[5] Satokawa S, Shibata J, Shimizu K-I, Satsuma A, Hattori T (2003) Appl. Catal. B:

Environnemental 42:179.

[6] Chaieb T, Delannoy L, Louis C, Thomas C (2013) Appl. Catal. B: Environmental 142$143: 780$

[7] Liu F, Yu Y, He H (2014) Chem. Commun. 50:8445.

[8] Chaieb T, Delannoy L, Costentin G, Louis C, Casale S, Chantry RL, Li ZY, Thomas C (2014) Appl. Catal. B: Environmental 156-157:192.

[9] Kamolphop U, Taylor SFR, Breen JP, Burch R, Delgado JJ, Chansai S, Hardacre C, Hengrasmee S, James SL (2011) ACS Catal. 1:1257.

[10] Petitto C,Delahay G (2012) Catal. Lett. 142:433.

[11] Ralphs K, D’Agostino C, Burch R, Chansai S, Gladden LF, Hardacre C, James SL, Mitchell J, Taylor SFR (2014) Catal. Sci. Technol. 4:531.

[12] Ralphs K, Chansai S, Hardacre C, Burch R, Taylor SFR, James SL (2015) Catal. Today 246:198

[13] Zhang R, Kaliaguine S (2008) Appl. Catal. B: Environmental 78:275.

[14] Franck JP, Freund E, Quéméré E (1984) J. Chem. Soc. Chem. Commun. 10:341.

[15] Lefèvre G, Duc M, Lepeut P, Caplain R, Fédoroff M (2002) Langmuir 18:7530.

[16] Carrier X, Marceau E, Lambert J-F, Che M (2007) J. Colloid Interface Sci. 308:429. 
[17] Mironenko RM, Belskaya OB, Talsi VP, Gulyaeva TI, Kazakov MO, Nizovskii AI, Kalinkin AV, Bukhtiyarov VI, Lavrenov AV, Likholobov VA (2014) Appl. Catal. A: General 469:472.

[18] Law HY, Blanchard J, Carrier X, Thomas C (2010) J. Phys. Chem. C 114:9731.

[19] Thomas C (2011) J. Phys. Chem. C 115:2253.

[20] Zhou R-S, Snyder RL (1991) Acta Cryst. 47:617.

[21] Pecharromán C, Sobrados I, Iglesias JE, González-Carreño T, Sanz J (1999) J. Phys. Chem. B 103:6160.

[22] Busca G (2013) Catal. Today 226:2.

[23] Bogdanchikova N, Meunier FC, Avalos-Borja M, Breen JP, Pestryakov A (2002) Appl. Catal. B 36:287.

[24] She X, Flytzani-Stephanopoulos M (2006) J. Catal. 237:79.

[25] Breen JP, Burch R, Hardacre C, Hill CJ (2005) J. Phys. Chem. B 109:4805.

[26] Venkov T, Hadjiivanov K, Klissurski D (2002) Phys. Chem. Chem. Phys. 4:2443.

[27] Szanyi J, Kwak JH, Chimentao RJ, Peden CHF (2007) J. Phys. Chem. C 111:2661.

[28] Pazé C, Gubitosa G, Orso Giacone S, Spoto G, Llabrés i Xamena FX, Zecchina A (2004) Topics Catal. 30/31:169.

[29] Deng H, Yu Y, He H (2015) J. Phys. Chem. C 119:3132.

[30] Sazama P, Čapek L, Drobná H, Sobalík Z, Dědeček J, Arve K, Wichterlová B (2005) J. Catal. 232:302.

[31] Kim PS, Kim MK, Cho BK, Nam I-S, Oh SH (2013) J. Catal. 301:65.

[32] Johnson II WL, Fisher GB, Toops TJ (2012) Catal. Today 184:166.

[33] Chansai S, Burch R, Hardacre C, Norton D, Bao X, Lewis L (2014) Appl. Catal. B: Environmental 160-161:356. 
[34] Männikkö M, Skoglundh M, Härelind H (2015) Catal. Today 258:454.

[35] Männikkö M, Wang X, Skoglundh M, Härelind H (2016) Appl. Catal. B: Environmental 180:291.

[36] Kyriienko P, Popovytch N, Soloviev S, Orlyk S, Dzwigaj S (2013) Appl. Catal. B:

Environmental 140-141:691.

[37] Deng H, Yu Y, Liu F, Ma J, Zhang Y, He H (2014) ACS Catal. 4:2776. 